\title{
Achieving the SDGs in Africa Through South-South Cooperation on Climate Change with China
}

\author{
Moritz Weigel and Alexander Demissie
}

\subsection{INTRODUCTION}

The Paris Agreement under the United Nations Framework Convention on Climate Change (UNFCCC) (United Nations [UN] 2015a) and the United Nations 2030 Agenda for Sustainable Development (2030 Agenda) with its 17 Sustainable Development Goals (SDGs) (UN 2015b) represent unprecedented multilateral commitments to a prosperous and sustainable future for life on Earth. There is a growing recognition that progress on achieving the 2030 Agenda and the SDGs is inextricably linked to progress on the implementation of the Paris Agreement and vice versa (German Development Institute/Deutsches Institut für Entwicklungspolitik [DIE] 2019; NewClimate Institute [NCI] 2018; Stockholm Environment Institute [SEI] 2017; United Nations Executive Office of the Secretary-General [UN EOSG] 2017; United Nations Framework Convention on Climate Change [UNFCCC] 2016; World Resources Institute [WRI] 2016). While climate action constitutes one of the SDGs, it is also interconnected with all other SDGs. Therefore, climate action offers a catalytic solution to all SDGs.

South-South cooperation $(\mathrm{SSC})^{1}$ on the SDGs and climate change is recognised by the SDGs and the Paris Agreement as an important means of support in addition to developed countries' obligations. Specifically, SDG 17 includes

M. Weigel $(\bowtie) \cdot$ A. Demissie

The ChinaAfricaAdvisory, Cologne, Germany

e-mail: weigel@chinaafricaadvisory.com
A. Demissie
e-mail: demissie@chinaafricaadvisory.com
(C) The Author(s) 2021
S. Chaturvedi et al. (eds.), The Palgrave Handbook of Development
Cooperation for Achieving the 2030 Agenda,
https://doi.org/10.1007/978-3-030-57938-8_28

605 
targets on finance, technology, and capacity-building that refer to SSC as a way of strengthening the means of implementation and revitalising the global partnership for sustainable development (UN 2019a). The Paris Agreement makes indirect reference to SSC in its Article 9.2 by encouraging developing countries to "provide or continue to provide [financial resources to assist developing-country Parties with respect to both mitigation and adaptation] voluntarily" (UN 2015a).

In this chapter, we argue that SSC on climate change (SSCCC) with China has a tremendous potential for African countries to realise their climate action priorities, as outlined in their nationally determined contributions (NDCs) under the Paris Agreement (UNFCCC 2019), and through this enable the achievement of the SDGs on the continent. Our analysis proceeds as follows.

First, we look at the linkages between climate action and the SDGs. Second, we review the overall evolution of SSCCC between China and African countries, based on which we apply the concept of "contested cooperation" (please refer to the introductory chapter of this book) by showcasing how China is using existing bilateral and multilateral channels for SSCCC with African countries as well as creating new platforms for cooperation with African partners in this context. China cooperates with multilateral institutions such as United Nations organisations on SSCCC with African countries by providing both financial and technical support, and through that gradually, but steadily, increasing the SSCCC portfolio of those organisations. At the same time, China contests existing cooperation mechanisms by expanding its bilateral support for SSCCC with African countries as well as by driving the establishment of new multilateral financial institutions that support low-emission, climate-resilient development as an alternative to the traditional development finance architecture (Cooper and Farooq 2015). Third, we look at African countries' climate action priorities and show how they tally with China's current SSCCC and pledges in this area. We conclude by looking at challenges for realising the full potential of SSC between China and African countries for low-emission, climate-resilient development and the achievement of the SDGs in Africa and offer recommendations on how to address these challenges, including through triangular cooperation with developed countries.

\subsection{ACHIEVING THE SDGs in Africa Through Climate Action}

There is a growing recognition by countries (UNFCCC 2016) and in research (DIE 2019; NCI 2018; SEI 2017; UN EOSG 2017; WRI 2016) that the implementation of the NDCs is inextricably linked to the achievement of the SDGs and vice versa. For example, "NDC-SDG Connections" (DIE 2019), which is a joint initiative of the German Development Institute/Deutsches Institut für Entwicklungspolitik and the Stockholm Environment Institute, shows the various connections and synergies between the NDCs and the 17 SDGs with their 169 targets. This tool aims to support policy-makers in 
identifying potential entry points for more coherent policies and action (see Fig. 28.1).

Another example of an analysis on linkages between climate action priorities of countries under the Paris Agreement and the SDGs is the recently published "SDG Climate Action Nexus" tool, which showcases hundreds of specific linkages between climate action and SDG targets (NewClimate Institute 2018). To date, the most comprehensive analysis on linkages between the NDCs and the SDGs with a focus on developing countries is a report jointly published by the United Nations Executive Office of the Secretary-General and the UNFCCC Secretariat. The report finds that more than three-quarters of developing countries' NDCs have clear linkages to 10 of the 17 SDGsnamely SDGs $2,6,7,8,9,11,12,13,15$, and 17-and more than half of the NDCs have linkages to SDGs 3, 4, and 14. Examples of how the SDG targets can be achieved through the implementation of activities spelt out in developing countries' NDCs include: SDG 2 (zero hunger) through climateresilient agriculture; SDG 6 (clean water and sanitation) through ensuring water access and integrated water management, improvement of sewerage systems, and wastewater treatment; SDG 7 (affordable and clean energy) through the proliferation of renewable energy and energy-efficiency technologies; SDG 9 (industry, innovation, and infrastructure) through improvement in production processes and the development of low-emission infrastructure; and SDG 15 (life on land), which is addressed by more than 90 per cent

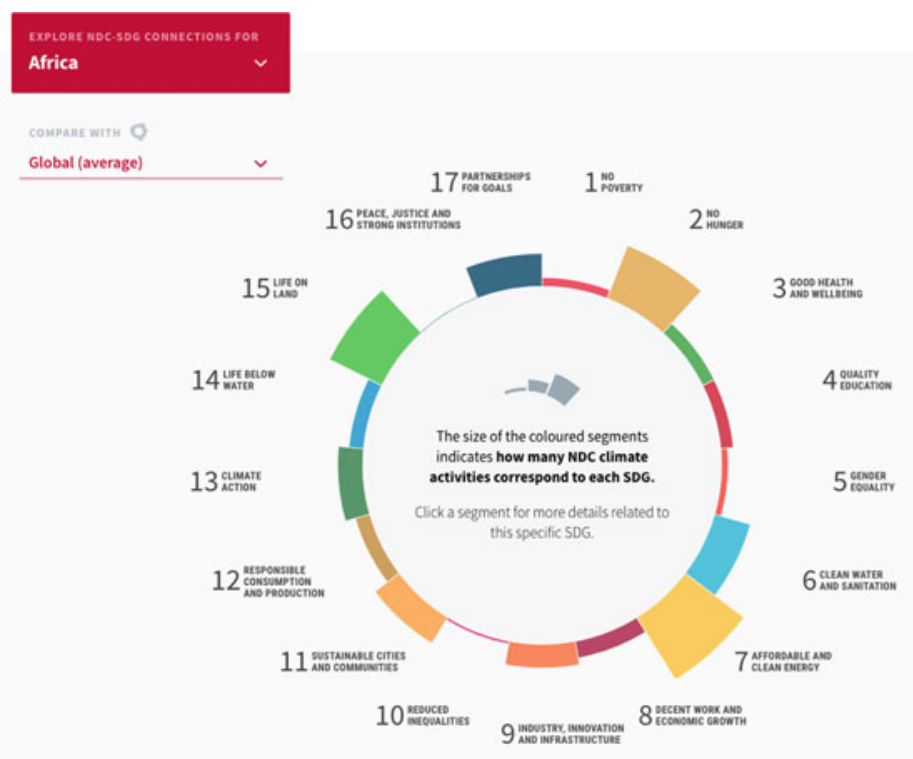

Fig. 28.1 "NDC-SDG Connections"- overview of linkages between African countries' NDCs and the SDGs (Source DIE [2019]) 
of the NDCs from developing countries that indicate actions on forest and land management issues. The report also includes case studies of South-South and triangular cooperation from those areas that feature most prominently in developing countries' NDCs, namely energy, land-use, transport, waste, agriculture, and water, showcasing how the achievement of specific SDGs is supported in each case (UN EOSG 2017).

The Fifth Assessment Report of the Intergovernmental Panel on Climate Change (IPCC) ${ }^{2}$ presents strong evidence for the adverse effects of climatic change-particularly on the health, livelihoods, and food security of people in African countries-and concludes that climate change poses a significant threat to socio-economic development in Africa (Intergovernmental Panel on Climate Change [IPCC] 2014a). Therefore, achieving the SDGs in Africa will not be possible without addressing climate change. With regard to lowemission development, the IPCC report states that African countries have abundant opportunities to adopt clean, efficient, low-emission technologies and practices while avoiding inefficient, fossil fuel-dependent infrastructure that more developed countries are locked into (IPCC 2014b). Utilising these opportunities will provide generous gains in economic productivity, human development, and quality of life (IPCC 2014b). As we show in the following sections, SSCCC has become an important part of African countries SSC with China. In this chapter, China thus serves as an example to illustrate the potential of SSCCC for achieving the SDGs in Africa.

\subsection{Evolution of South-South Cooperation on Climate Change Between China and Africa}

China has a long history of SSC with African countries that reaches back to the 1950s (Information Office of the State Council of the People's Republic of China [IOSC] 2011). However, the first official reference to cooperation on addressing climate change can only be found in "China's Africa Policy", published in 2006, which states that China will promote cooperation with Africa on climate change by increasing scientific and technological cooperation (IOSC 2006). ${ }^{3}$ Since then, climate change has increasingly become a focus of China's SSC with African countries.

In 2009, China and African countries agreed to include cooperation on addressing climate change as one of the new areas for cooperation under the Forum on China-Africa Cooperation (FOCAC) ${ }^{4}{ }^{4}$ which serves as the main platform for collective consultation and dialogue on political, economic, and sociocultural cooperation between China and African countries (Forum on China-Africa Cooperation [FOCAC] 2009). China's first white paper on foreign aid, published in 2011, confirmed the prominent role of African countries in China's SSC and highlighted climate change as a new area of China's foreign aid (IOSC 2011). 
At FOCAC's fifth ministerial meeting in 2012, China and African countries expressed satisfaction with the progress in cooperation in protecting the environment and addressing climate change in recent years and underscored the willingness to continue exchanges and cooperation in these areas. China pledged to continue to support African countries in building capacity for climate change adaptation and mitigation as well as for sustainable development (FOCAC 2012). China's latest white paper on foreign aid includes a dedicated section on SSCCC, with Africa stating that China has "actively helped African countries improve their ability to cope with climate change, and strengthened cooperation with them in meteorological satellite monitoring, new energy development and utilization, desertification prevention and control, and urban environmental protection" (IOSC 2014).

Furthermore, China's second Africa policy paper, published shortly before the 2015 FOCAC summit in Johannesburg, stipulated cooperation on climate change as being one of the six areas for which China's assistance would be primarily used, and that China will boost and consolidate cooperation with African countries under the UNFCCC ("China's second Africa policy paper" 2015). In the FOCAC Johannesburg Declaration and Action Plan, China and African countries acknowledged that climate change is exacerbating existing development challenges in Africa and is placing additional burdens on the national budgets and efforts of African countries to achieve sustainable development. China and participating African countries reiterated their intentions to strengthen their policy dialogue on climate change as well as deepen cooperation in tackling climate change, in particular as regards climate change monitoring; climate risk and vulnerabilities reduction; strengthening resilience; promoting adaptation, support for mitigation in terms of capacity-building, technology transfer, as well as financing for monitoring and implementation (FOCAC 2015a, b).

The vision for China's Belt and Road Initiative, also published in 2015, by China's National Development and Reform Commission-the supreme macroeconomic planning and management body - together with the ministries of Foreign Affairs and Commerce, also includes provisions on "tackling climate change" and pursuing low-emission and climate-resilient infrastructure construction and operation (National Development and Reform Commission [NDRC] 2015a). This is of importance, as 37 of the 53 African countries that have diplomatic relations with China had already joined the Belt and Road Initiative by September 2018 ("China signs MOUs with 37 African countries" 2018).

The outcome documents of the latest FOCAC summit, held in 2018, reaffirmed this commitment to further deepening "pragmatic cooperation with African countries under the framework of Climate Change South-South Cooperation, and help African countries strengthen climate change adaption capabilities through providing assistance in kind and capacity-building training to jointly meet the challenge posed by climate change". In particular, China will help increase African countries' resilience to climate change by advancing 
sustainable agriculture, forest management, and organic farming, and through the efficient management of natural resources as well as supporting disaster prevention and raising public awareness (FOCAC 2018a, b).

\subsection{Contested Cooperation: Old and New Channels of China's South-South Cooperation on Climate Change with African Countries}

Over the past decade, China has emerged as one of the leading developing countries on SSCCC (Ha et al. 2015; Weigel 2016). China's SSCCC with African countries has not only increased through established bilateral and multilateral channels, but also through China's creation of new bilateral and multilateral mechanism, as described below. This leads to "regime shifting" (Morse and Keohane 2014) within international climate change cooperation through the adjustment of existing-and the introduction of new-approaches, in line with China's aid principles (Weigel 2016).

Since 2008, China's SSCCC projects in Africa are listed in an annual report titled "China's Policies and Actions on Addressing Climate Change" and in China's two white papers on foreign aid published in 2011 (IOSC 2011 ) and 2014 (IOSC 2014). For example, China has signed bilateral agreements on "Complimentary Supplies for Addressing Climate Change" with Benin, Burundi, Cameroon, Egypt, Ethiopia, Ghana, Madagascar, and Nigeria. It has also implemented projects on bioenergy with Guinea, Sudan, and Tunisia; on solar and wind power with Ethiopia, Morocco, and South Africa; and on capacity-building on low-emission industrial development and energy policies, water resources management and conservation, forestry, desertification prevention and control, early warning systems, and satellite weather monitoring in many African countries (IOSC 2014).

Most significantly, in 2015, China's president, Xi Jinping, announced the establishment of a $\$ 3.1$ billion (20 billion Chinese yuan) South-South Cooperation Climate Fund. This pledge is significant, not only because it is the largest single pledge for supporting climate action in developing countries made by any country to date, but also because it represents a significant increase from China's previous spending on SSCCC of about \$30 million per year (Weigel 2016). Even if it were spent over 15 years, the pledge would equal a more than sixfold increase per annum. Figure 28.2 illustrates the significance of this pledge based on 5-year, 10-year, and 15-year spending scenarios.

The establishment of the fund is also part of China's climate action pledge under the Paris Agreement, as spelt out in its NDC (NDRC 2015b). However, due to administrative challenges and changes in institutional arrangementsincluding the establishment of China's new Ministry of Ecology and Environment (MEE), which now includes the SSCCC portfolio- the fund has not yet become fully operational. Until China's recent ministerial reshuffling in 2018, the National Development and Reform Commission (NDRC) $)^{5}$ was in charge 


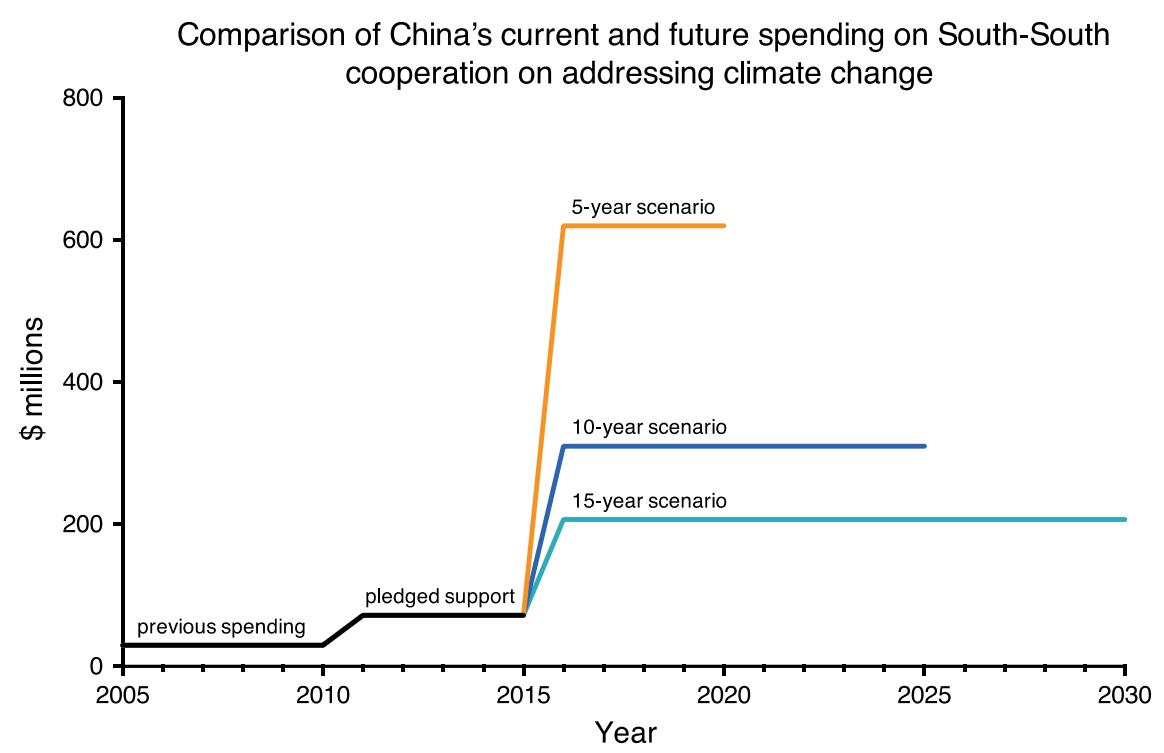

Fig. 28.2 Current and future spending scenarios on China's SSCCC (Source Weigel [2016])

of bilateral SSCCC projects, with project implementation being led by the NDRC-affiliated National Center for Climate Change Strategy and International Cooperation. SSCCC is now under the responsibility of China's MEE in coordination with China's new aid agency, the China International Development Cooperation Agency. There seems to be consistency in bilateral SSCCC projects as the National Center for Climate Change Strategy and International Cooperation continues its implementation role under MEE leadership.

In addition to its bilateral channels, China has been increasingly using existing multilateral channels under the umbrella of the United Nations for advancing SSCCC with African countries. For example, China established dedicated funds and programmes on climate-resilient agriculture with the Food and Agriculture Organization of the United Nations (FAO) ${ }^{6}$ (FAO 2019), on climate change adaptation with the United Nations Environment Programme (UNEP) ${ }^{7}$ (UNEP 2014, 2015a, b, 2019), and on broadly advancing SSCCC within the United Nations System together with the United Nations Office for South-South Cooperation (UNOSSC) (2019b). For example, China provided $\$ 6$ million to the United Nations Executive Office of the Secretary-General (Ministry of Foreign Affairs of the People's Republic of China 2014), which was used to establish the Southern Climate Partnership Incubator (SCPI), also known as the United Nations Climate Partnerships for the Global South. The SCPI was launched on the margins of the signing of the Paris Agreement in 2016 to foster, support, and 
promote South-South and triangular cooperation for climate action by facilitating network and partnership-building, assist with policy exchange, technical assistance, and capacity-building between countries of the Global South, and accelerate access to green technologies to Southern countries on favourable terms. The SCPI has been instrumental in developing the first United Nations Action Plan on South-South Climate Cooperation (2017-2021), which was adopted in November 2017 (UNOSSC 2019c). China has also been increasingly engaging on triangular cooperation with United Nations entities and African countries to address climate change, for example with the United Nations Development Programme (UNDP) on sharing expertise and technologies for renewable energy generation in Burundi, Ghana, and Zambia and supporting drought management and desertification control in Ethiopia and Kenya (UNDP 2015).

While China has been increasingly using existing bilateral and multilateral channels for advancing SSCCC with African countries, it has also created new channels for this purpose, most prominently the already mentioned SouthSouth Cooperation Climate Fund. Following the announcement of the \$3.1 billion fund by President Xi in September 2015, he specified in his speech at the United Nations Climate Change Conference in Paris in November 2015 that China will pursue a "10-100-1000" South-South cooperation initiative, which aims to implement 10 low-carbon development demonstration projects, 100 climate mitigation and adaptation projects in developing countries, as well as provide climate change capacity-building opportunities for 1000 representatives from developing countries. He also said that China will continue to promote international cooperation in such areas as clean energy, disaster prevention and mitigation, ecological protection, climate-smart agriculture, and low-carbon and smart cities ("Full text of President Xi's speech" 2015).

In the same year, China also established the South-South Cooperation Assistance Fund and pledge $\$ 2$ billion to the fund, which has the overall objective of supporting developing countries to achieve the SDGs and therefore also has strong relevance for SSCCC. The fund has been operational since 2016, and grant applications are required to demonstrate clearly how the proposed project supports the achievement of specific SDGs, SDG targets, and indicators. To date, there has not been a public call for applications, but internal calls for proposals were received by government-affiliated entities and multilateral organisations based in China.

In addition to the two funds that are, so far, mainly focussed on expanding bilateral cooperation, China has also spearheaded the establishment of two major new development banks, namely the New Development Bank (NDB) ${ }^{8}$ and the Asian Infrastructure Investment Bank (AIIB), ${ }^{9}$ which are both committed to supporting low-emission, climate-resilient development. These new multilateral development finance institutions are often perceived as challenging existing institutions (Callaghan and Hubbard 2016), but they can equally be seen as a response to the growing financing gaps for development, including climate finance, which has not been provided adequately to 
developing countries (De Haan and Warmerdam 2017). The NDB makes it clear that it was established "to support infrastructure and sustainable development efforts in BRICS [Brazil, Russia, India, China, South Africa] and other underserved, emerging economies for faster development through innovation and cutting-edge technology" (New Development Bank [NDB] 2019a). Addressing climate change is among the core principles of the bank's Environmental and Social Framework, which commits the bank to promote mitigation and adaptation measures by pursuing the development of a green economy; promoting the conservation of natural resources, including energy and water; supporting sustainable land-use management and urban development; and "climate proofing of its infrastructure financing and investments". The coverage of the environmental impact assessment explicitly includes the assessment of "both the potential impacts of the project on climate change as well as the implications of climate change on the project", the development of "both mitigation or adaptation measures as appropriate", and the identification of "opportunities for no- or low-carbon use, where applicable, and for reducing emissions from the project" (NDB 2016). The Environmental and Social Framework also requires the integration of "principles of cleaner production into product design and production processes with the objective of conserving raw materials, energy and water" (NDB 2016). Furthermore, efforts need to be made to reduce project-related greenhouse gas (GHG) emissions during design and operation, and projects with significant GHG emissions are encouraged to quantify direct and indirect emissions, in line with national protocols (NDB 2016). So far, South Africa is the NDB's only African member state, but the bank foresees opening up membership beyond its five founding members in the future. The NDB has already provided a total of $\$ 680$ million for the financing of energy and transport projects in South Africa (NDB 2019b).

The AIIB is also committed to addressing climate change and makes specific reference to supporting the implementation of the Paris Agreement by contributing to "mitigation, adaptation and the redirection of financial flows" (Asian Infrastructure Investment Bank [AIIB] 2016). In particular, the bank "stands ready [...] to assist its Clients in achieving their nationally determined contributions" and with the formulation of long-term, low GHGemission development strategies (AIIB 2016). The AIIB aims to "prioritize investments promoting greenhouse gas emission neutral and climate resilient infrastructure, including actions for reducing emissions, climate-proofing and promotion of renewable energy" (AIIB 2016). The bank's environmental and social standards include a dedicated section on climate change, which calls for the development of mitigation or adaptation measures to reduce climate change-related risks and an assessment of the impacts of any project on climate change, including emissions, as well as the implications of climate change for the project (AIIB 2016). Furthermore, projects should identify opportunities for reducing GHG emissions, enhancing adaptive capacity, strengthening resilience, and reducing vulnerability to climate change, including through 
incorporating climate-proofing into the project and promoting the use of renewable energy (AIIB 2016). The AIIB also "promotes the conservation of energy, water and other resources; supports sustainable land use management; and encourages making best use of green growth and low-carbon technologies, renewable energy, cleaner production, sustainable transport systems and sustainable urban development" (AIIB 2016). Furthermore, the AIIB supports "reporting on greenhouse gas emissions for implementation of the Paris Agreement" by financing measures to quantify and report to national authorities direct and indirect project-related emissions (AIIB 2016). Eleven African countries are already either Members ${ }^{10}$ or Prospective Members ${ }^{11}$ of the AIIB, and the bank is already co-financing renewable energy (AIIB 2017) and sustainable rural sanitation projects (AIIB 2018) in Egypt, providing a total of $\$ 510$ million as long-term debt financing.

In the context of how cooperation with these new multilateral development banks can contribute to climate action-and through this support the achievement of the SDGs-it is important to note that the strengthening of implementation rules for the banks' Environmental and Social Frameworks, including public access to information, will be key for ensuring that the banks' aspirations on addressing climate change and fostering development are met in practice (GEGAfrica 2017; Germanwatch 2019; Heinrich Böll Foundation 2019).

As explained in more detail in the introductory chapter of this book, contested cooperation describes the current development cooperation landscape that is being shaped by "ongoing processes of institution shifting and institution creation within established forms of development cooperation and new types of collaboration". In the context of China's SSCCC with African countries, we see institution-shifting through China's contribution to the relative expansion of SSCCC with African countries under FAO, UNDP, UNEP, and UNOSSC, as well as institution-creation through the expansion of China's bilateral SSCCC channels with African partners and the drive to establish new multilateral financial institutions that support climate action. As illustrated in Table 28.1, contested cooperation leads to a certain level of re-focussing of the work of existing institutions, such as the aforementioned United Nations organisations, and the establishment of new institutions in this context, such as the Southern Climate Partnership Incubator. At the same time, within the concept of contested cooperation, either existing institutions incorporate new types of collaboration, such as South-South and triangular cooperation in the case of the United Nations organisations, or new types of collaboration are pursued by newly created institutions, such as the AIIB, the NDB, or China's emerging South-South Cooperation Climate Fund. 
Table 28.1 Contested cooperation matrix for China's South-South cooperation on climate change with African countries

\begin{tabular}{|c|c|c|c|}
\hline \multicolumn{4}{|l|}{ Contestation } \\
\hline & & Institution-shifting & Institution-creation \\
\hline \multirow[t]{5}{*}{ Cooperation } & \multirow[t]{2}{*}{$\begin{array}{l}\text { Established } \\
\text { cooperation }\end{array}$} & $\frac{\text { Updating international }}{\text { institutions }}$ & \multirow{2}{*}{$\begin{array}{l}\text { Proliferating } \\
\text { international } \\
\text { institutions } \\
\text { Creation of } A I I B \text { and } \\
\text { NDB }\end{array}$} \\
\hline & & $\begin{array}{l}\text { Re-focussing the work of } \\
\text { United Nations organisations } \\
\text { on SSCCC with African } \\
\text { countries }\end{array}$ & \\
\hline & \multirow{3}{*}{$\begin{array}{l}\text { New types of } \\
\text { collaboration }\end{array}$} & \multirow{2}{*}{$\frac{\text { Collaborating in }}{\text { international institutions }}$} & Piloting collaboration \\
\hline & & & Collaboration under the \\
\hline & & $\begin{array}{l}\text { Establishing the Southern } \\
\text { Climate Partnership } \\
\text { Incubator }\end{array}$ & $\begin{array}{l}\text { China South-South } \\
\text { Cooperation Climate } \\
\text { Fund }\end{array}$ \\
\hline
\end{tabular}

Source Authors

\subsection{African Countries' Climate Action Priorities}

African countries' NDCs include specified goals or targets for reducing GHG emissions as well as adaptation components that describe how the country is adversely impacted by climate change and what the country intends to do to adapt to these impacts (UNFCCC 2019). An analysis of all NDCs submitted by African countries to the UNFCCC under the Paris Agreement found that agriculture, land-use and forestry, water, energy, and transport range among the priority areas for climate action on the continent (Weigel and Demissie 2017). The above section on China's SSCCC with African countries has shown that cooperation is already taking place in all of these priority areas. In the areas of agriculture, land-use and forestry, there is not only bilateral cooperation between China and African countries on introducing practices and technologies that increase climate-resilience (Bräutigam 2015; FOCAC 2009, 2012, 2015a, 2018b; IOSC 2011, 2014), but also increasing cooperation through partnerships with multilateral organisations, for example with the FAO (2019) and the International Bamboo and Rattan Organisation (2019). In the area of water, there are also many examples of bilateral and multilateral cooperation, for example under the UNEP-China-Africa Cooperation Programme. This programme includes cooperation on the planning, development, and demonstration of new technologies for safe water supply, water quality, and ecosystem monitoring; the demonstration of new wastewater treatment technologies, drought early warning systems, and adaptive technologies; the development and demonstration of water-saving techniques for dry land agriculture and agricultural mapping; and the development and demonstration of technologies for combating desertification (UNEP 2014, 2015a, b). There is a broad spectrum of SSCCC projects between China and African countries in the area 
of energy, ranging from supporting the development of renewable energy policies to providing technical support for the planning, development, and operation of renewable energy projects (UNFCCC 2018b), the donation of energy-efficient equipment (NDRC 2013), the financing of large-scale renewable energy projects (Ismail 2018), as well as support for setting up local production facilities (Ismail 2018). Finally, in the area of transport, cooperation between African countries and China has brought about pioneering low-emission transport systems, such as through renewable energy-powered Light Rail Transit in Ethiopia's capital, Addis Ababa, as well as the electrified railway line between Addis Ababa and Djibouti (UNFCCC 2018b). We have seen that addressing climate change is a prerequisite for achieving the SDGs and the 2030 Agenda in Africa. We have also seen that China has emerged as an important partner for African countries on SSCCC by using existing, and creating new, bilateral and multilateral channels of support. We have further seen that China's past and current SSCCC with Africa tallies with African countries' climate action priorities, and that pledges made by China on future support hold a tremendous potential for supporting Africa's climate action priorities.

\subsection{Unlocking the Full Potential of South-South Cooperation on Climate Change Between China and African Countries}

In order to unlock the full potential of SSCCC between China and African partners, the following should be considered by Chinese, African, and other decision-makers in this area:

- A global survey on China's SSCCC undertaken by UNDP in 2015 (Weigel 2016) found that many African countries are not fully aware of how to enter into SSCCC with Chinese partners. In order to address this challenge, China should publish a comprehensive overview of its bilateral and multilateral support for SSCCC, including information on how African countries can access support. Such an overview should include SSCCC and related activities under all FOCAC funds and mechanisms and be carried out by all relevant ministries, including the Ministry of Agriculture, the Ministry of Commerce, and the Ministry of Science and Technology, among others.

- China should fully operationalise its South-South Cooperation Climate Fund and make information on the fund's access, operational modalities, and activities publicly available. Given the size of the fund, with a pledged amount of $\$ 3.1$ billion, its operation could significantly contribute to further unlocking the full potential of SSCCC. Activities of the fund should include direct support for the development and implementation of SSCCC projects in African countries. Access to the fund should be 
quick, unbureaucratic, and transparent to serves as an efficient and effective complement to the often complex access requirements for climate finance provided by developed countries, for example through the Green Climate Fund. ${ }^{12}$

- The South-South Cooperation Climate Fund should contribute to ensuring that the new development finance architecture emerging under China's leadership through the AIIB and the NDB is living up to its commitment of fostering low-emission and climate-resilient development. Such work could have a catalysing effect and support developing countries in integrating climate change aspects into their socio-economic programmes, far beyond the scope of the South-South Cooperation Climate Fund. Furthermore, the enforcement of strong environmental safeguards in the operation of the new institutions would help ensure that the efforts of the South-South Cooperation Climate Fund are not undermined by other funds through, for example, the financing of coal-fired power plants.

- African countries should build on pledges made by China under the Belt and Road Initiative and FOCAC regarding SSCCC and proactively identify concrete ways of implementing their climate action priorities with support from Chinese partners. For example, as the "10 low-carbon development demonstration projects" are still being identified, African countries pursuing the development of sustainable special economic zones, such as Ethiopia, Kenya, Rwanda, and South Africa, could present a concrete cooperation proposal in this regard.

- African countries should also get actively involved with the AIIB and the NDB and seek ways to use these institutions for implementing their NDCs, in particular with regard to low-emission, climate-resilient infrastructure development and renewable energy projects. The NDB is only now opening up to a broader membership, which should be used by African countries to influence, and benefit from, these new development finance institutions for implementing their NDCs. Such an involvement should be pursued as a complement to existing engagements with other multilateral financial institutions.

- Multilateral climate funds should follow the successful example of the Adaptation Fund to provide SSC grants that foster peer-to-peer learning between developing countries on the successful application and management of funds (Adaptation Fund 2019).

- Developed countries should support SSCCC between China and African countries through triangular cooperation, in line with agreed targets and indicators of SDG 17 as well as the outcome document of the Second High-level United Nations Conference on South-South Cooperation (UN 2019b), which was adopted by all United Nations Member States in April 2019 as a blue print for future South-South and triangular cooperation for the achievement of the SDGs. In particular, existing pledges in this area should be realised, such as by the European Union, 
which already committed itself in 2016 to turn "what is often perceived as EU-China competition in Africa into greater cooperation" and to pursue "joint approaches" to "speed up the implementation of the Paris Agreement wherever possible, including the implementation of Nationally Determined Contributions" (European Commission 2016). ${ }^{13}$ Germany is also well-positioned to spearhead triangular cooperation on climate change with Chinese and African partners by building on its triangular cooperation strategy (Federal Ministry for Economic Cooperation and Development 2013) and fully utilising the recently established SinoGerman Center for Sustainable Development (2019), which inter alia aims to support low-emission, climate-resilient infrastructure development in African countries.

\section{Notes}

1. For the purpose of this article "South-South cooperation" is understood as a broad framework for collaboration among developing countries in political, economic, social, cultural, environmental, and technical domains, through which developing countries share knowledge, skills, expertise, and resources to meet their development goals through concerted efforts (UNOSSC 2019a). South-South cooperation on climate change is therefore defined as any of the above-listed collaborations between developing countries that aim to reduce GHG emissions or support the adaptation to the adverse effects of climate change.

2. The IPCC is a body of the United Nations dedicated to providing the world with an objective, scientific view of climate change; its natural, political, and economic impacts and risks; and possible response options.

3. However, China has already been engaged in renewable energy projects with African countries since the 1980s, for example in the area of biogas, and started undertaking small-scale hydro, solar, and wind power projects and training programmes on climate change, forest management, and desertification in many countries in the 1990s and 2000s (IOSC 2011).

4. Following proposals from Benin, Ethiopia, Madagascar, and Mauritius, FOCAC was established in 2000 by China in collaboration with African countries ( $\mathrm{Li}$ 2012). FOCAC ministerial meetings take place every three years. The ministerial meetings were elevated to summits with the participation of heads of state and government in the years 2006, 2015, and 2018. Further information on FOCAC is available at: http://www.focac.org.

5. Theoretically the NDRC needed to be involved in any work on international cooperation on climate change-related matters. However, in practice, this was not always the case due to the broad scope of climate change-related work and the absence of a clear definition of what constitutes SSCCC (Weigel 2016).

6. China has been actively involved in, and largely contributed to, FAO's SSC Programme since its launch in 1996. In 2008, China donated $\$ 30$ million to FAO to establish an SSC Trust Fund, which funds the FAO-China SSC Programme, which supports many African countries to promote climate-smart agriculture. In 2014, China added \$50 million to the Trust Fund (FAO 2019). 
7. The UNEP-China-Africa Cooperation Programme focusses on enhancing the capacity of African countries to address climate change through technology transfer and capacity-building, in particular with regard to ecosystem management, disaster reduction, climate change adaptation, and renewable energy generation.

8. The NDB was established in 2015 with an initial subscribed capital of $\$ 50$ billion and initial authorised capital of $\$ 100$ billion. The five founding members-Brazil, China, India, Russia, and South Africa-hold equal shares and voting power. The NDB is headquartered in Shanghai, China. Its first Regional Center is located in Johannesburg, South Africa.

9. Following a proposal by China in 2013 , the AIIB was established in 2015 with an initial subscribed capital of $\$ 100$ billion. The allocated shares are based on the size of each member country's economy. Voting power is divided into basic votes, share votes, and founding member votes. China has, by far, the largest voting power, with about 27 per cent of the total votes (AIIB 2019). The AIIB is headquartered in Beijing, China.

10. Egypt, Ethiopia, Madagascar, and Sudan (AIIB 2019).

11. Algeria, Ghana, Kenya, Libya, Morocco, South Africa, and Togo (AIIB 2019).

12. Established in 2010, the Green Climate Fund launched a Readiness and Preparatory Support Programme (Readiness Programme) in 2014 to help developing countries fulfil its complex requirements for receiving financial support. However, in practice, even accessing the Green Climate Fund Readiness Programme is challenging for many developing countries and requires support from Northern providers to become "ready" for the Readiness Programme (UNFCCC 2018a).

13. In the EU-China Leaders' Statement on Climate Change and Clean Energy, published in July 2018, both sides stated their commitment to "explore possibilities for triangular cooperation on promoting sustainable energy access, energy efficiency and low greenhouse gas emission development in other developing countries and assist them to increase the capacities in combating climate change, with particular focus on least developed countries, small island developing states and African countries, as reflected in these countries' national climate plans, strategies and policies” (European Union 2018).

\section{REFERENCES}

Adaptation Fund. (2019). South-South cooperation grants. https://www.adaptationfund.org/readiness/readiness-grants/south-south-cooperation-grants/.

AIIB (Asian Infrastructure Investment Bank). (2016). Environmental and social framework. https://www.aiib.org/en/policies-strategies/_download/environmentframework/20160226043633542.pdf.

AIIB. (2017). Egypt Round II Solar PV Feed-in Tariffs Program. https://www.aiib. $\mathrm{org} / \mathrm{en} /$ projects/approved/2017/egypt-round-II-solar-pv-feed-in-tariffs-program. html.

AIIB. (2018). Program document of the Asian Infrastructure Investment Bank: Arab Republic of Egypt Sustainable Rural Sanitation Services Program. https://www. aiib.org/en/projects/approved/2018/_download/egypt/document/egypt-sustai nable-rural.pdf. 
AIIB. (2019). Members and prospective members of the bank. https://www.aiib.org/ en/about-aiib/governance/members-of-bank/index.html.

Bräutigam, D. (2015). Will Africa feed China? New York, NY: Oxford University Press.

Callaghan, M., \& Hubbard, P. (2016). The Asian Infrastructure Investment Bank: Multilateralism on the Silk Road. China Economic Journal, 9(2), 116-139.

China signs MOUs with 37 African countries, AU on B\&R development. (2018, September 7). Xinhuanet. http://www.xinhuanet.com/english/2018-09/07/c_1 37452482.htm.

China's second Africa policy paper. (2015, December 5). ChinaDaily. http://www. chinadaily.com.cn/world/XiattendsParisclimateconference/2015-12/05/content_2 2632874.htm.

Cooper, A. F., \& Farooq, A. B. (2015). Testing the club dynamics of the BRICS: The New Development Bank from conception to establishment. International Organizations Research Journal, 10(2), 1-15.

De Haan, A., \& Warmerdam, W. (2017). China's foreign aid: Towards a new normal? ResearchGate. https://www.researchgate.net/publication/311992075_China\%27s_ Foreign_Aid_Towards_a_new_normal.

DIE (German Development Institute/Deutsches Institut für Entwicklungspolitik). (2019). NDC-SDG connections. https://klimalog.die-gdi.de/ndc-sdg/country/ Africa.

European Commission. (2016). Joint communication to the European Parliament and the Council: Elements for a new EU strategy on China. http://eeas.europa.eu/arc hives/docs/china/docs/joint_communication_to_the_european_parliament_and_ the_council_-_elements_for_a_new_eu_strategy_on_china.pdf.

European Union. (2018). Joint statement of the 20th EU-China summit. https:// eeas.europa.eu/delegations/china_en/48424/Joint\%20statement $\% 20$ of $\% 20$ the $\%$ 2020th\%20EU-China\%20Summit.

FAO (Food and Agriculture Organization of the United Nations). (2019). FAOChina South-South cooperation programme. http://www.fao.org/3/a-i4700e.pdf.

Federal Ministry for Economic Cooperation and Development. (2013). Triangular cooperation in German development cooperation: Position paper (BMZ Strategy Paper 5). Bonn: Author.

FOCAC (Forum on China-Africa Cooperation). (2009). Forum on China-Africa cooperation Sharm El Sheikh Action Plan. https://www.focac.org/eng/zywx_l/ zywj/t626387.htm.

FOCAC. (2012). The Fifth Ministerial conference of the Forum on China-Africa cooperation Beijing Action Plan (2013-2015). https://www.focac.org/eng/zywx_l/ zywj/t954620.htm.

FOCAC. (2015a). Declaration of the Johannesburg Summit of the Forum on ChinaAfrica cooperation. https://www.focac.org/eng/zywx_1/zywj/tl327960.htm.

FOCAC. (2015b). The Forum on China-Africa Cooperation Johannesburg Action Plan (2016-2018). https://www.focac.org/eng/zywx_1/zywj/tl327961.htm.

FOCAC. (2018a). Beijing Declaration-Toward an even stronger China-Africa community with a shared future. https://www.focac.org/eng/zywx_l/zywj/tl5 94324.htm.

FOCAC. (2018b). Forum on China-Africa Cooperation Beijing Action Plan (20192021). https://www.focac.org/eng/zywx_1/zywj/t1594297.htm. 
Full text of President Xi's speech at opening ceremony of Paris climate summit. (2015, January 12). China Daily. http://www.chinadaily.com.cn/world/Xiattends Parisclimateconference/2015-12/01/content_22592469.htm.

GEGAfrica. (2017). The New Development Bank as an advocate of country systems. https://www.saiia.org.za/wp-content/uploads/2017/08/GA_Thl_PB-pri nsloo_20170831.pdf.

Germanwatch. (2019). Aligning the Asian Infrastructure Investment Bank with the Paris Agreement and the SDGs: Challenges and opportunities. http://www.german watch.org/sites/germanwatch.org/files/AIIB_Report_web_0.pdf.

Ha, S., Hale, T., \& Ogden, P. (2015). Climate finance in and between developing countries: An emerging opportunity to build on. Global Policy, 7(1), 102-108.

Heinrich Böll Foundation. (2019). The Asian Infrastructure Investment Bank: A multilateral bank where China sets the rules. https://th.boell.org/sites/default/ files/boell_aiib-studie_en_web_v0l.pdf.

International Bamboo and Rattan Organisation. (2019). Dutch-Sino-East Africa Bamboo Development Programme. https://www.inbar.int/project/dutch-sino-eastafrica-bamboo-development-project/.

IOSC (Information Office of the State Council of the People's Republic of China). (2006). China's Africa policy. http://en.people.cn/200601/12/eng20060112_ 234894.html.

IOSC. (2011). China's foreign aid. http://english.gov.cn/archive/white_paper/ 2014/09/09/content_281474986284620.htm.

IOSC. (2014). China's foreign aid. http://english.gov.cn/archive/white_paper/ 2014/08/23/content_281474982986592.htm.

IPCC (Intergovernmental Panel on Climate Change). (2014a). AR5 climate change 2014: Impacts, adaptation and vulnerabilities. https://www.ipcc.ch/report/ar5/ wg $2 /$.

IPCC. (2014b). AR5 climate change 2014: Mitigation of climate change. https:// www.ipcc.ch/report/ar5/wg3/.

Ismail, A. (2018, May 10). Egypt signs MOU with China's GCL for \$2 billion solar panel factory. Reuters. https://www.reuters.com/article/us-egypt-solar/egyptsigns-mou-with-chinas-gcl-for-2-billion-solar-panel-factory-idUSKBN1IBIWI.

Li, A. (2012). The Forum on China-Africa cooperation: From a sustainability perspective. http://awsassets.panda.org/downloads/the_forum_on_china_afr ica_cooperation_l.pdf.

Ministry of Foreign Affairs of the People's Republic of China. (2014). Zhang Gaoli attends UN Climate Summit and delivers speech. https://www.fmprc.gov.cn/ce/ ceun/eng/chinaandun/economicdevelopment/climatechange/.

Morse, J. C., \& Keohane, R. O. (2014). Contested multilateralism. The Review of International Organizations, 9(4), 385-412.

NCI (NewClimate Institute). (2018). NDC update report special edition: Linking NDCs and SDGs. https://newclimate.org/2018/05/07/ndc-update-report-spe cial-edition-linking-ndcs-and-sdgs.

NDB (New Development Bank). (2016). New Development Bank: Environmental and social framework. https://www.ndb.int/wp-content/uploads/2017/02/ndb-enviro nment-social-framework-20160330.pdf.

NDB. (2019a). Mission. https://www.ndb.int/about-us/essence/mission-values.

NDB. (2019b). Projects. https://www.ndb.int/projects/list-of-all-projects. 
NDRC (National Development and Reform Commission). (2013). China's policies and actions for addressing climate change. http://en.ndrc.gov.cn/newsrelease/201 311/P020131108611533042884.pdf.

NDRC. (2015a). Vision and actions on jointly building Silk Road economic belt and 21st-century maritime Silk Road. http://en.ndrc.gov.cn/newsrelease/201503/t20 150330_669367.html.

NDRC. (2015b). Enhanced actions on climate change: China's intended nationally determined contributions. https://www4.unfccc.int/sites/ndcstaging/Publis hedDocuments/China\%20First/China\%27s\%20First\%20NDC\%20Submission.pdf.

SEI (Stockholm Environment Institute). (2017). Exploring connections between the Paris Agreement and the 2030 Agenda for Sustainable Development. https:// mediamanager.sei.org/documents/Publications/SEI-PB-2017-NDC-SDG-Connec tions.pdf.

Sino-German Center for Sustainable Development. (2019). Trilateral cooperation projects. https://sg-csd.org.

UN (United Nations). (2015a). Paris Agreement. https://unfccc.int/sites/default/ files/english_paris_agreement.pdf.

UN. (2015b). Transforming our world: The 2030 Agenda for Sustainable Development. A/RES/70/1. https://sustainabledevelopment.un.org/content/docume nts $/ 21252030 \% 20$ Agenda\%20for\%20Sustainable\%20Development\%20web.pdf.

UN. (2019a). Sustainable Development Goals knowledge platform: Sustainable Development Goals. https://sustainabledevelopment.un.org.

UN. (2019b). Buenos Aires Outcome Document of the Second High-level United Nations Conference on South-South Cooperation. https://digitallibrary.un.org/rec ord $/ 3802251$ ? ln $=$ en.

UNDP (United Nations Development Programme). (2015). Fast facts-Climate change in China. http://www.cn.undp.org/content/dam/china/docs/Publicati ons/UNDP-CHFast $\% 20$ Facts\%20on\%20Climate\%20Change $\% 202$.pdf.

UN EOSG (United Nations Executive Office of the Secretary-General). (2017). Catalysing the implementation of nationally determined contributions in the context of the 2030 Agenda through South-South cooperation. https://unfccc.int/sites/default/ files/ssc_ndc_report.pdf.

UNEP (United Nations Environment Programme). (2014). New ChinaUNEP agreement to boost South-South cooperation on climate change adaptation. https://www.unenvironment.org/news-and-stories/press-release/new-chinaunep-agreement-boost-south-south-cooperation-climate.

UNEP. (2015a). The UNEP-China-Africa cooperation programme: Enhancing the role of ecosystem management in climate change adaptation report. https://www. unenvironment.org/news-and-stories/press-release/unep-china-africa-cooperationprogramme-enhancing-role-ecosystem.

UNEP. (2015b). UNEP-China-Africa cooperation on the environment. http://www. unep.org/rso/portals/118/documents/unep_china/unep-china-africa.pdf.

UNEP. (2019). China Trust Fund. Strengthening strategic cooperation on environmental conservation. https://wedocs.unep.org/bitstream/handle/20.500.11822/ 22316/Chinese $\% 20$ Trust $\% 20$ Fund\%20Brochure\%20Phase\%20II\%20Eng.pdf?seq uence $=1$ \& isAllowed $=\mathrm{y}$.

UNFCCC (United Nations Framework Convention on Climate Change). (2016). Aggregate effect of the intended nationally determined contributions: An update. Synthesis report by the Secretariat. http://unfccc.int/resource/docs/2016/cop22/ eng/02.pdf. 
UNFCCC. (2018a). Adaptation Committee workshop on accessing the readiness and preparatory support programme of the Green Climate Fund for adaptation. https:// unfccc.int/sites/default/files/resource/SB48.AC_.1.pdf.

UNFCCC. (2018b). Potential of South-South and triangular cooperation on climate technologies for advancing implementation of nationally determined contributions and national adaptation plans. http://unfccc.int/ttclear/misc_/StaticFiles/gnw oerk_static/brief9/7a74a2fl7f204b6bal7flec965da70d7/f4e36lcd56d4463a8d aa4ab29al254db.pdf.

UNFCCC. (2019). NDC registry. https://www4.unfccc.int/sites/NDCStaging/ Pages/All.aspx.

UNOSSC (United Nations Office for South-South Cooperation). (2019a). About South-South and triangular cooperation. https://www.unsouthsouth.org/about/ about-sstc/.

UNOSSC. (2019b). Southern climate partnership incubator. https://www.unsouthso uth.org/our-work/partnership-building/southern-climate-partnership-incubator/.

UNOSSC. (2019c). United Nations Action Plan on South-South Climate Cooperation (2017-2021). https://www.unsouthsouth.org/south-south-cooperation-actionplan-for-climate-change-engagement-strategy-2017-2021/.

Weigel, M. (2016). More money, more impact? China's climate change South-South cooperation to date and future trends. http://www.cn.undp.org/content/china/ en/home/library/south-south-cooperation/more-money-more-impact-china-s-cli mate-change-south-south-coop.html.

Weigel, M., \& Demissie, A. (2017). A new climate trilateralism? Opportunities for cooperation between the EU, China and African countries on addressing climate change (DIE Discussion Paper 8/2017). Bonn: German Development Institute/Deutsches Institut für Entwicklungspolitik (DIE).

WRI (World Resources Institute). (2016). Examining the alignment between the intended nationally determined contributions and Sustainable Development Goals. https://www.wri.org/sites/default/files/WRI_INDCs_v5.pdf.

Open Access This chapter is licensed under the terms of the Creative Commons Attribution 4.0 International License (http://creativecommons.org/licenses/by/4.0/), which permits use, sharing, adaptation, distribution and reproduction in any medium or format, as long as you give appropriate credit to the original author(s) and the source, provide a link to the Creative Commons license and indicate if changes were made.

The images or other third party material in this chapter are included in the chapter's Creative Commons license, unless indicated otherwise in a credit line to the material. If material is not included in the chapter's Creative Commons license and your intended use is not permitted by statutory regulation or exceeds the permitted use, you will need to obtain permission directly from the copyright holder.

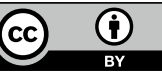

